\title{
Environmental change in the Late Pleistocene and later Holocene at Wanda site, Soroako, South Sulawesi, Indonesia
}

\author{
Geoffrey Hope* \\ Department of Archaeology and Natural History, Research School of Pacific and Asian Studies, Australian National University, \\ Canberra ACT 0200, Australia
}

Received 17 December 1999; received in revised form 2 June 2000; accepted for publication 25 September 2000

\begin{abstract}
This paper reports the pollen analysis of an $8 \mathrm{~m}$ core from a mire at $445 \mathrm{~m}$ altitude and $2^{\circ} \mathrm{S}$ latitude on ultramafic soils near the western shore of Lake Matano, South Sulawesi. The area is almost undisturbed by humans and the record is believed to cover about 50-75,000 yr B.P., with some breaks in the record. A section from 17,000 to around 5500 yr B.P. and the last 1000 years of the record may be missing or disturbed. The results show that montane forest grew around the site continuously through the late Pleistocene with a maximum increase in higher altitude taxa from 35,000 to after 17,000 yr B.P., the time of glacial maxima elsewhere. Also in this period, increases in grass and Casuarina indicate possible drier conditions. The Holocene sections record lower altitude forest with increased taxonomic diversity, including secondary species. The results show that vegetation in the region has been sensitive to climatic change, the Pleistocene ecology being consistent with a temperature change of about $2.5-3.5^{\circ} \mathrm{C}$ with a phase up to $50 \%$ drier than present. The site climate was possibly affected by shelf exposure in the Gulf of Bone due to lower sea levels. However the tropical forest demonstrates overall long term stability in which changes in dominance may reflect minor shifts in disturbance and tree longevity. A distinctive record of fine charcoal occurs throughout the deposit. This shows that the forest has never been continuously fire-free for a very long time. The cause of the fires may be natural as no evidence for human occupation was discerned. (C) 2001 Elsevier Science B.V. All rights reserved.
\end{abstract}

Keywords: Tropical forest; Vegetation history; Late Pleistocene; Holocene; S-E Asia; Palaeoecology

\section{Introduction}

The tropical area between mainland Asia and Australia-New Guinea is of great importance in understanding modern climatic processes and palaeoclimatic changes. The area has strong throughflows from the warm western Pacific Ocean to the Indian Ocean, and is a major source of latent heat for the globe. In detail the climatic patterns are complex and poorly understood, with considerable variation

\footnotetext{
* Tel.: +61-2-6249-3283; fax: +61-2-6249-4917.

E-mail address: geoff.hope@coombs.anu.edu.au (G. Hope).
}

in seasonality and rainfalls over short distances. The biota is also virtually undescribed in most areas although the flora and vertebrate fauna has been widely collected. Palaeoecological studies have been carried out in Java (e.g. Stuijts, 1993; Van der Kaars and Dam, 1995), Kalimantan (Morley, 1981), Sulawesi (Gremmen, 1992; Dam et al., 2001), and New Guinea (Hope and Tulip, 1994; Haberle, 1994). Marine cores are the only sources of pollen data in the intervening area, cores having been studied near Halmahera, the Banda Sea and south of Sumba on the Lombok rise (Van der Kaars, 1991, 1997; Van der Kaars et al., 2001; Barmawijaja et al., 1993). 
Palynology has identified distinct climatic responses of the regional vegetation with relatively higher influxes of montane pollen types such as Castanopsis being identified in late Pleistocene glacial records. At Bandung, Van der Kaars and Dam also identify the peak glacial stages as time of lower rainfall and even aridity. This is less apparent in the marine cores to the east and north of Java, nor in the 60,000 year terrestrial record from northern Irian Jaya (Hope and Tulip, 1994). (All ages in this paper are calibrated years B.P. except where indicated.)

Marine records are difficult to interpret in terms of the land vegetation, being particularly influenced by waterborne pollen from rivers, which can vary as sea level changes. Barmawijaja et al. (1993) interpret an 18,000 year record from Halmahera (ca. $3^{\circ} \mathrm{N}$ ) as representing minor changes at sea level but a steep lapse rate upslope leading to a shift in upper montane boundaries by a few hundred metres. This interpretation is consistent with claims of stable sea surface temperatures through the late Pleistocene in the warm waters north of New Guinea. However, Hope and Tulip (1994) find evidence for significant vegetation shifts at $750 \mathrm{~m}$ altitude in Irian Jaya consistent with temperature change of $-4^{\circ} \mathrm{C}$ compared to present. This degree of change has also been supported by recent re-interpretation of marine cores (Van der Kaars et al., 2001). Terrestrial sites record local vegetation and can provide much more sensitive indicators of climate at a location than is possible with most marine cores. A range of sites across the eastern Indonesian region will be needed to establish the degree of vegetation response to Pleistocene and Holocene climate change.

This paper reports on a long record from Wanda site, a small swamp at $450 \mathrm{~m}$ in Sulawesi, an enormous island straddling the equator. The swamp occurs in a solutional hollow formed in ultramafic rocks. Studies of these oligotrophic sites (Hope et al., 1988; Hope and Tulip, 1994; Hope and Pask, 1998) have demonstrated that they accumulate sediments extremely slowly and can thus preserve very long records by comparison to other tropical swamps which have much better nutrition. The flora on ultramafic areas is relatively simple and slow to recover from disturbance, improving the visibility and persistence of complex changes.

The relative roles of climate change, natural disturbances and human activity are difficult to separate as causes of vegetation change. Long records should involve comparisons of environments before and after human occupation, but at sufficient resolution to detect short term change as well. The occupation of Australia and New Guinea has been established as having occurred at least 50,000 years ago, and can be presumed to be even older on mainland Asia, although no very old sites have been recorded there. In Sulawesi occupation has been demonstrated over only the last 20,000 years although Halmahera and Morotai have returned dates of 33,000 B.P. for occupation (Bellwood, 1997, 1998).

\section{Study region}

\subsection{Location}

The town of Soroako lies on the shore of Lake Matano, at the head of the Gulf of Bone, which separates the southeast and southwest arms of the island (Whitten et al., 1987). The study area is the Matano Fault Zone, a tectonically formed inter-montane valley, which contains several large lakes, the largest of which are Lakes Matano, Towuti and Poso. Lake Matano $\left(2^{\circ} 33^{\prime} \mathrm{S}, 121^{\circ} 23^{\prime} \mathrm{E}\right)$ is the second deepest lake at $382 \mathrm{~m}$ altitude and $565 \mathrm{~m}$ depth. The lake is $28 \mathrm{~km}$ in length and averages about $8 \mathrm{~km}$ wide, and is in an ultramafic catchment except for a small area of limestone on the southern shore. The highest points in the catchments are 1400-1700 m. Wanda Swamp is situated on a relict plateau at $400-580 \mathrm{~m}$ altitude $2 \mathrm{~km}$ south east of the lake and $5 \mathrm{~km}$ east of Soroako. The plateau is currently strip-mined for nickel which accumulates in the upper parts of giant laterite profiles up to $40 \mathrm{~m}$ in thickness.

\subsection{Climate}

Lake Matano and Soroako lie in the humid tropics and lack marked seasonality or much year-to-year variability. The rainfall at Soroako is $2737 \mathrm{~mm}$ per year and has a pattern of heavy afternoon and evening showers, often associated with moderate winds over the lake. Humidity is high and the skies often cloudy, although there is no cloud zone forming at a fixed altitude on the nearby mountains. Temperatures at 
Soroako $(385 \mathrm{~m})$ average $24^{\circ} \mathrm{C}$ with maxima of $31^{\circ} \mathrm{C}$ and minima of $22^{\circ}$.

\subsection{Geology and geomorphology}

Sulawesi may be a composite land mass, welded from several plate fragments due to the migration of the Australian Plate into the Pacific since the Cretaceous. The Matano fault zone may represent one of the welds, the southeast arm having migrated as part of the $2000 \mathrm{~km}$ transcurrent Irian Fault (Pigram and Davies, 1987; Metcalfe, 1990; Whitten et al., 1987). The oldest rocks in the area are Mesozoic (probably Cretaceous) limestones, shales and marls which outcrop to the southwest of Soroako (Ahmad, 1977). A serpentinite forms a contact with overlying ultramafics, principally peridotite and harzburgite which form the bulk of the area and may be early Tertiary in age (Soeria Atmadja et al., 1974). These rocks are the result of sea floor emergence and overthrusting. An offset of $16 \mathrm{~km}$ has been noted along the Matano fault.

The general topography in the region is mountainous, but slopes are usually gentle and not greatly dissected. The weathering is intense with saprolites to $60 \mathrm{~m}$ or more in some areas. Soils on the harzburgites are massive red earths with a lateritic profile developed in some areas, possibly as a palaeosol. Nickel enrichment in the upper levels of these soils is mined using open cut methods, and mineral reserve drilling has established that the deep profiles are of considerable extent around Lake Matano. Large areas of the ultramafic rocks lack coherent drainage and a karstic internally draining topography has developed on level ground. Dunites and harzburgites are soluble in tropical conditions and in the Soroako area form dolines with a relief of 10-30 m and some hectares in extent. The dolines may be influenced by faults as some are arranged on linear axes. The soils, which can contain over $60 \%$ iron oxide, also erode by piping and illuviation so that some pseudo-karst processes may be involved. However the land surface is generally very stable.

\subsection{Vegetation}

The natural vegetation of the ultramafic soils of the Verbeek mountains is closed canopy forest, with three major altitudinal zones represented on the ultrabasic substrates (Whitten et al., 1987; Cox and Collins, 1991; Van Balgooy and Tantra, 1986). On slopes below about $500 \mathrm{~m}$ on sedimentary rocks is a lowland forest with a complex structure and floristics, notable for its palm flora and climbers. There are no detailed descriptions but in the Soroako area Van Balgooy and Tantra note Ficus, Celtis, Chionanthus, Fagraea, Caesalpinia, Prunus, Pterocarpus, Sterculia, Trichospermum and Radermachera. Around Malili, in disturbed forest, are larger-leafed Elaeocarpus, Moraceae, Eugenia, Canarium, Pometia, Terminalia and Euphorbiaceae. Palms and aroid climbers are very frequent.

The forest on ultramafic substrates is very distinctive. At the site and extending up to $600-800 \mathrm{~m}$ is a mesophyll-microphyll forest about $25-35 \mathrm{~m}$ in height, without emergents, although Van Balgooy and Tantra (1986) suspect that any large specimens of Agathis demara may have all been cut out in the past. Trees are densely spaced but normally only 40$60 \mathrm{~cm}$ trunk diameter, with almost no understory (except a few gingers and the fern Schizaea dichotoma) and sparse litter. Eugenia, Kjellbergiodendron, Meterosideros and Tristania spp. (Myrtaceae) are prominent in the canopy, as are Lauraceae (Cinnamomum, Cryptocarya and Neolitsea). Castanopsis buruana and Lithocarpus sp (Fagaceae), Ilex cf. cymosa, Hopea celebica, Agathis celebica, Decussocarpus sp and Podocarpus sp were occasional. Taxa in the Bignoniaceae, Burseraceae, Clusiaceae, Elaeocarpaceae, Melastomataceae, Moraceae, Myristicaceae, Proteaceae, Rosaceae, Rubiaceae, Rutaceae, Sapindaceae, Sapotaceae and Theaceae are common. Pandans, palms and cycads are not plentiful and lianas are also uncommon with the exception of Freycinetia, Korthalsia and Calamus species.

Open areas are a tangle of the ferns Gleichenia, Dipteris conjugata and Dicranopteris sp and shrubs of Melastoma, rather than the grasses and aroids found on richer soils. Secondary scrubs with Alphitonia sp, Homolanthus, Trema, Callicarpa species, bracken and Scaevola oppositifolia take over clearings. Where the surface soil has eroded or on exposed laterite crusts, regeneration is extremely difficult and a sparse shrubland of Baeckia frutescens establishes, with scattered orchids, lycopods, and Rhododendron cf. maius. Disturbed roads are colonised by Macaranga gigantophylla and climbing bamboo such as 
Dinochloa sp. Gymnostoma sumatrana forms stands on landslip scars along the Larona River but does not seem to occupy the primary rainforest at Lake Matano although it is found in the lake edge vegetation. Lakes have a riparian fringe of a small Pandanus species and tall sedges such as Scirpus mucronatus but swamps are generally open sedgelands of Machaerina rubiginosa, reflecting poor nutrition.

At higher altitudes Castanopsis and Lithocarpus become important in the forest which becomes generally microphyll and lower. Van Balgooy and Tantra (1986) describe the vegetation at $1000 \mathrm{~m}$ on a limestone hill west of Soroako. There the forest was $10 \mathrm{~m}$ taller than that on ultramafic rocks, more diverse floristically and mixed with less patch dominance. Ilex and Sapindaceae were common but no families dominated. No good descriptions exist of high altitude ultramafic forests near Lake Matano but in Central Sulawesi forest above $1500 \mathrm{~m}$ on granitic rocks is dominated by Lithocarpus glutinosus, L. elegans and Castanopsis acuminatissima. Air photographs of montane ultramafic areas near Lake Matano show a stunted, even canopy to the summits, so very marked altitudinal changes may not occur in the area.

\subsection{Human influences}

Little is known about early occupation in the Soroako region, and human presence has only been demonstrated over the past 14,000 years in South Sulawesi (Bellwood, 1997), with rice presumably being introduced in the last few millenia. Sago palm (Metroxylon sagu) was formerly utilised around the head of the Gulf of Bone, where it was the major staple. The Luwu kingdom, based on trade, developed in the northeast Bone area after 700 B.P. and the iron produced in the Matano area from laterite ore was an important production of this society, ore and metal reaching Java and northern Sumatra (Bulbeck and Prasetyo, 1999). Prior to the development of Soroako for nickel mining about 1970 , an estimated 400 people lived in three villages around Lake Matano and the whole shoreline was visited by canoe. Gardens of maize, sweet potato and taro were planted on deeper alluvial soils, often after clearing secondary scrub. Rice cultivation seems to have been restricted to non-ultramafic soils north west of the lake.

Large areas of grass fallow occur west of the lake, but in other areas secondary shrublands resulted. Away from the lake, the grasslands on ultramafic soils do not seem to be important to present day inhabitants, although a mosaic of fire scars is evident. The ultramafic soils are not desirable for agriculture and the forest is mostly primary, except for some modern timber extraction, Callophyllum being a favoured genus. However hunting trails are common across the area, extending into the closed forest. These are followed by rattan palm (Calamus spp.) collectors who travel into the hills and use water buffalo to drag back bundles of stems. Tracks also cross the range to villages on the north coast.

\section{Site description}

\subsection{Wanda Mire}

During a survey of potential palaeoecology sites in Sulawesi in 1984 the large lakes in the region (Danau Matano, D. Towuti and D. Poso) were visited, but they lack marginal swamps and were too deep to be cored with available equipment. However peat-filled basins were shown to the author by Mike Nicholls within the lease area of PT INCO, which operates a large nickel mine near Soroako. Maps and air photos prepared by INCO and kindly made available revealed dozens of completely closed basins on gently undulating areas on the west and southeast of Lake Matano (Fig. 1). An extensive network of tracks put in for drilling rigs allowed access to several of these basins, some of which are being utilised as disposal sites for overburden (e.g. Betsy site), waste water (Elaine site) and as the town dump (Bonsora Site). The average closed basin is $10-30 \mathrm{~m}$ deep, varies in size from 4 to 20 ha and contains a sedge swamp or shallow (1$4 \mathrm{~m}$ deep) lake. A probe of Bonsora site was reported (Agus Suparman, pers. comm.) as having penetrated soft sediment to about $35 \mathrm{~m}$, and peat was being forced to the surface of another as overburden was placed in it. Several sites, however, such as Anoa, Diana and Debbie proved to be floored by hard orange muds. After testing several sites, Wanda site was chosen for further study as it lay only $0.5 \mathrm{~km}$ from the Bonsora site but in undisturbed forest.

Wanda site is termed a telaga mati (dead, or infilled, lake) by local informants. The 14 ha catchment 


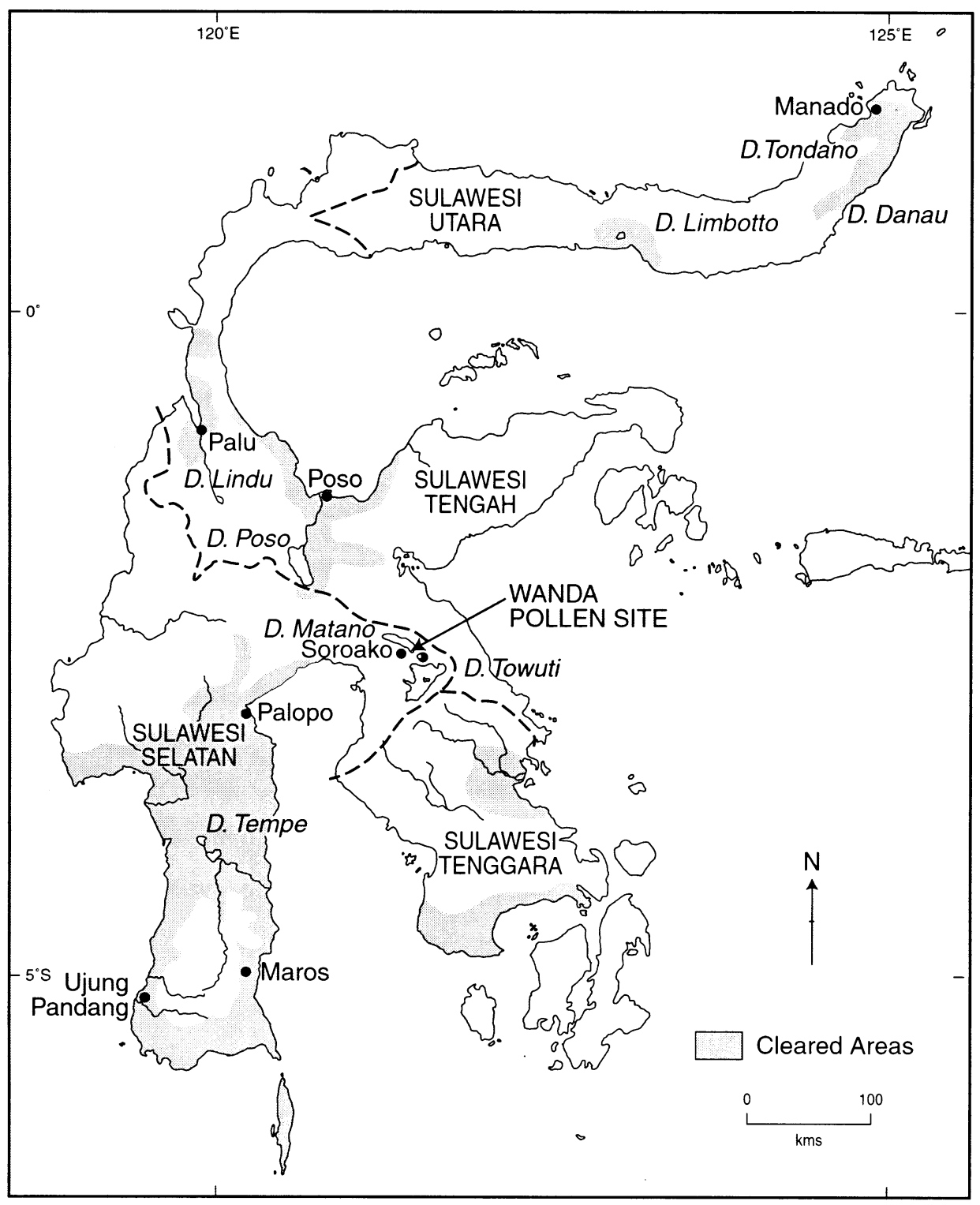

Fig. 1. Location diagram of Sulawesi showing major lakes.

hollow has no tributaries but water travels through the soil to a central sedge swamp 4.6 ha in extent The swamp is a level oval mire about $250 \mathrm{~m}$ long and $180 \mathrm{~m}$ broad forming a shallow lake averaging $50 \mathrm{~cm}$ in depth but rising to $1.5 \mathrm{~m}$ after heavy rain (Fig. 2). There is no overflow, and water is presumed to percolate through the regolith.

The lake itself is an open sedgeland of Lepironia articulata and Machaerina rubiginosa. In some parts of the mire low shrubs of Meterosideros sp grow, entangled by Nepenthes miriabilis. Surface mud is visible but often covered by a clear gelatinous (?algal) ooze up to $4 \mathrm{~cm}$ deep supporting a yellow flowering Utricularia sp. The muds are soft near the surface but become firm at $30 \mathrm{~cm}$ depth. There is a narrow zone of marginal vegetation consisting of a 


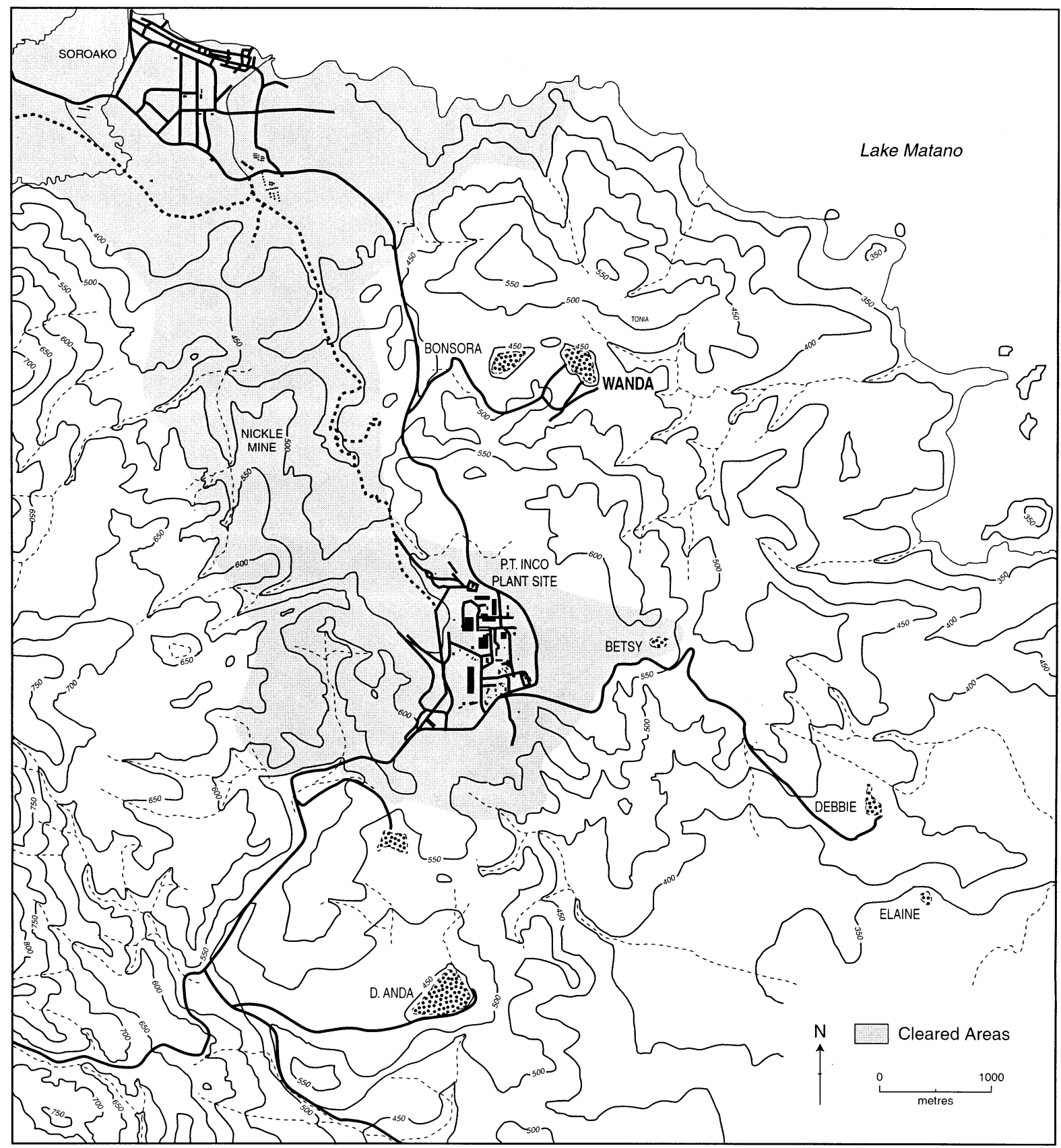

Fig. 2. Location diagram of the Soroako area and ultramafic depressions.

dense stand of Scleria polycarpa and Schoenus laevinux up to $2 \mathrm{~m}$ in height, above scattered Utricularia sp, Scirpus mucronatus and Eriocaulon sp in open shallow water. The edge includes stands of Gleichenia (cf. bolanica), often festooned with the pitchers of Nepenthes miriabilis and clambering Flagellaria indica. The mire edge community grows in only slightly shallower conditions to the main mire area, 
so it seems likely that it is responding to nutrient inflows from the surrounding slopes.

Prior to the bulldozing of modern tracks in the area the catchment seems to have been undisturbed, with no evidence of fire or cutting. However the former foot track from Soroako to Wawandula may have passed close to the site. An area of shallow water was marked by cut stakes which were probably remnants of a fish trap of unknown age. Small fish were seen in the water, although how they reached the site is a mystery. Wild hens roost in the forest next to the lake and troops of macaques were occasionally seen.

The catchment is mostly covered by a relatively uniform mixed forest about $25 \mathrm{~m}$ in height with a lower mixed species layer of small trees. A line transect showed a high stem density of 225 stems/ha but relatively low basal area of $7.5 \mathrm{~m}^{2} / \mathrm{ha}$. A scattered lower strata of seedlings and $1 \mathrm{~m}$ high saplings occurs with occasional ferns such as Schizaea and Cycas rumphii. Lianes and palms are rare inside the canopy. A few hectares have been cleared for tracks and these support a secondary woodland of Macaranga gigantea, Trema amboinensis and Adinandra sp. with open areas covered by bracken and other ferns and masses of Flagellaria indica.

\subsection{Stratigraphy and dating}

An $850 \mathrm{~cm}$ section of lake muds (SKW 86) was obtained to the south of the centre of the mire using Livingstone and Russian (D section) borers in January 1986. The core consisted of soft algal mud becoming firmer below $3.5 \mathrm{~m}$. Wood fragments are common below $3.5 \mathrm{~m}$. Below $7.5 \mathrm{~m}$ the sediment was a dense amorphous organic mud. Coring was halted by increasingly dense organic material, with no sign of basement, and the full depth of organic sediments is still unknown although $10.5 \mathrm{~m}$ was reached with a probe. The choice of coring site was arbitrary, as a transect of test probes and cores showed that the whole basin contains at least $8 \mathrm{~m}$ of organic muds except within $4 \mathrm{~m}$ of the margin (Fig. 3). A second core (SKW90) was taken in January 1990, about $25 \mathrm{~m}$ from the earlier core and about $12 \mathrm{~m}$ from the margin of the swamp in an attempt to resolve a dating inversion encountered in the central core. This $240 \mathrm{~cm}$ core consisted of $15 \mathrm{~cm}$ of soft brown mud with sedge debris over firmer brown algal muds to the base of the core.

Extremely low inputs of inorganic materials and nutrients occur through the history of the site. A few bands of reddish clay occur in SKW86 at $10-17 \mathrm{~cm}$, and some clay was present at 235, 404 and $445 \mathrm{~cm}$. These bands reflect the inwash of iron-rich surface soils, so it is possible that some erosion events in the vicinity of the lake could have affected the nutrient balance of the lake. These minor sedimentary changes in the organic content may reflect tree throw or other surface disturbances in the catchment.

Wood and well preserved leaves were encountered occasionally in both cores. Radiocarbon samples were collected from duplicated sections and packaged on site, with the exception of AMS samples which were run on acid and alkali insoluble residues from $1 \mathrm{~cm}$ core samples. No complete vegetation survey was attempted although specimens of all aquatic plants were obtained and forest transects recording the surrounding tree taxa were undertaken (Table 1).

In the 1986 core samples SKW 86/1 to 86/5 were collected in the field from fresh duplicate core sections. Samples were treated with hot $10 \% \mathrm{HCl}$, rinsed with distilled water and dried before dating. A stratigraphic inversion is apparent between 107 and $332 \mathrm{~cm}$, and the cause of the anomaly may reflect overturn of older material. Although the upper $235 \mathrm{~cm}$ of the core is very soft, the material is not obviously churned and the date for SKW 86/2 at $332 \mathrm{~cm}$ was thought to be in error. In order to sort out the dating anomaly in the top section of the core, the SKW90 core was dated. Four sections were wet sieved, with only the fine fraction $(<500 \mu \mathrm{m})$ taken for dating. The fine fractions were treated with hot $10 \% \mathrm{HCl}$, rinsed with distilled water, and dried. Results from this core (SKW 90/6-9) provide evidence for a phase of relatively rapid infill and show that this section covers the period from 5500 years ago to around $3300 \mathrm{yr}$ B.P. This result did not resolve the initial problem so a further sample, SKW 86/10 from $350 \mathrm{~cm}$ in the 1986 core was dated by AMS. The result, $2610 \pm 12014 \mathrm{C}$ yr B.P., is identical to SKW 86/2, and supports the interpretation that the upper $3.6 \mathrm{~m}$ of SKW86 is late Holocene sediment accumulated in a hollow, possibly formed by fire or karstic subsidence. The date for initiation of this section is similar to the estimated age at which 


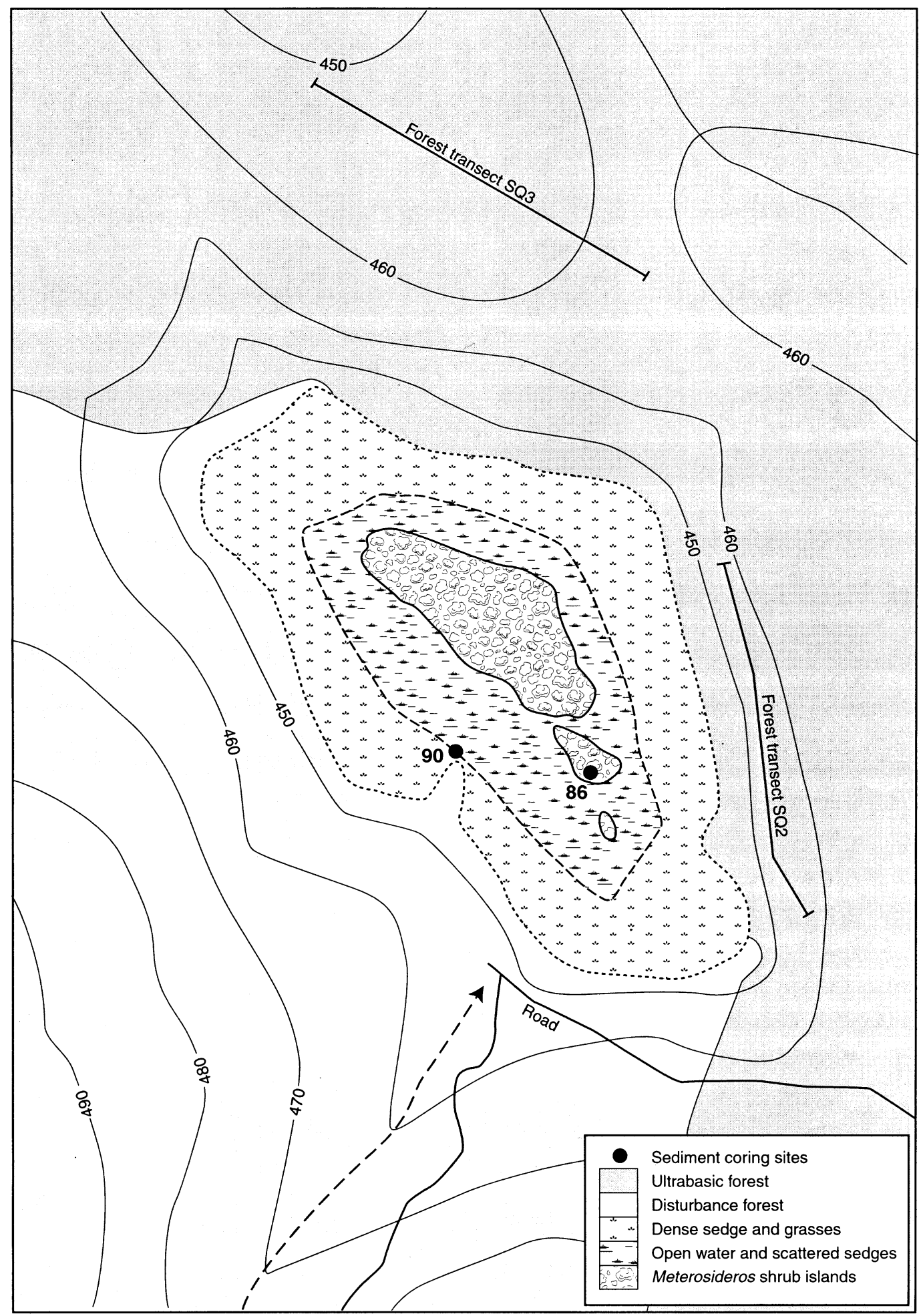

Fig. 3. Wanda site vegetation and location of coring sites. 
Table 1

Radiocarbon Dates and Calibrated Ages, Lake Wanda, Sulawesi [calibrated ages are the age range at 95\% limit using Calib 4.2 (Stuiver and Braziunas, 1993)]

\begin{tabular}{lrrlrl}
\hline Core & Depth cm & Cal age B.P. & Median age B.P. & 14C date yr B.P. & Lab no. \\
\hline SKW 86/1 & $100-115$ & $5490-5040$ & $\mathbf{5 2 6 5}$ & $4610 \pm 80$ & ANU 5340 \\
SKW 86/2 & $325-340$ & $2870-2450$ & $\mathbf{2 6 6 0}$ & $2610 \pm 80$ & ANU 5341 \\
SKW 86/10 AMS & 350 & $2930-2360$ & $\mathbf{2 6 4 5}$ & $2610 \pm 120$ & OZD 406 \\
SKW 86/3 & $485-500$ & $18,040-16,890$ & $\mathbf{1 7 4 6 5}$ & $14,560 \pm 130$ & ANU 5342 \\
SKW 86/11 AMS & 550 & & est 35,000 & $30,500 \pm 500$ & OZD 407 \\
SKW 86/4 & $610-625$ & & est $>\mathbf{4 0 k a}$ & $35,370 \pm 1180$ & ANU 5343 \\
SKW 86/5 & $735-750$ & est $>\mathbf{4 0 k a}$ & $33,640 \pm 1140$ & ANU 5344 \\
SKW 90/6 & $60-70$ & $4260-3810$ & $\mathbf{4 0 3 5}$ & $3670 \pm 90$ & ANU 9310 \\
SKW 90/7 & $110-120$ & $4660-4270$ & $\mathbf{4 4 6 5}$ & $4020 \pm 80$ & ANU 9309 \\
SKW 90/8 & $175-185$ & $5050-4790$ & $\mathbf{4 9 2 0}$ & $4310 \pm 80$ & ANU 9308 \\
SKW 90/9 & $226-234$ & $5660-5310$ & $\mathbf{5 4 8 5}$ & $4770 \pm 90$ & ANU 9307 \\
\hline
\end{tabular}

sedimentation ceases in the SKW90 core, supporting a site-wide event. If this interpretation is correct, then the SKW 86/1 date is the result of mixing of adjacent older sediments, or an inversion slump. These processes might also affect the pollen spectra.

The dating results also indicate that there is a gap of at least 14,000 years, from 17,000 to $2700 \mathrm{yr}$ B.P., in the SKW86 section at about $350-380 \mathrm{~cm}$ depth. The last 2000 years of this gap is covered by the SKW90 section. The time range of the SKW86 600-380 cm interval seems to be ca. 35,000-17,000 B.P. Below this, samples SKW 86/4 and 86/5 have ${ }^{14} \mathrm{C}$ ages that are not significantly different from each other at the $2 \sigma$ level. The long term sedimentation rate, of $1.4 \mathrm{~cm} /$ $100 \mathrm{yr}$ from $550 \mathrm{~cm}$ (SWK 86/11) to $617.5 \mathrm{~cm}$ (SKW $86 / 4$ ), suggests minimum ages of $43,500 \mathrm{yr}$ B.P. at the level of SKW 86/5 and $47500 \mathrm{yr}$ B.P. at the base of the SKW 86 core. Even older ages are implied by the rate of $0.60 \mathrm{~cm} / 100 \mathrm{yr}$ between SKW3 and 4, and by the highly compressed state of the lower peats, which may be more than 65,000 years old. However, slowing or cessation of sedimentation may have occurred during a more open grassland phase that occurs between 600 and $440 \mathrm{~cm}$ depth. It is also possible that the deep sediments may be much older than suggested here, since the near-limit dates may have been distorted by minor contamination of deeper levels. One possible source is the leaching of younger carbon that may be occurring as has been shown for similar karstic deposits in ultramafic areas (Hope et al., 1988).

The Wanda record demonstrates episodes when sedimentation was very slow, had ceased or had even possibly been lost by erosion. Such an episode may occur near the base of the core, and certainly in the periods 17,000-3000 yr B.P., and from $2500 \mathrm{yr}$ B.P. to present. The core is thus not a continuous record.

\section{Pollen diagram}

Samples were removed from the core in the field. In the laboratory $4 \mathrm{ml}$ samples were prepared following standard techniques. Pollen was reasonably abundant in most slides and pollen counted exceeded 200 in most levels. Samples from SKW86 at 3, 35, 650, 720 , and below 760, were below 150 counts and the basal samples 800,840 and $846 \mathrm{~cm}$ could not be brought to a satisfactory pollen sum. A relative pollen diagram (Fig. 4a, b) has been prepared using TILIA (Grimm, 1988). Tree and tree fern pollen percentages are calculated using a pollen sum of all dryland woody plants. Herbs, swamp taxa, unknowns and fern spores (other than tree ferns) are calculated on a sum of total pollen and spores, excluding unknowns. Unknowns make up $10-20 \%$ of the spectra but are mostly dicotyledonous types which probably represent lower altitude trees and shrubs whose pollen morphology is still poorly known.

The pollen diagram is presented as three segments, using the radio carbon ages and classification to combine both the SKW86 and 90 cores to present as complete a sequence as possible. The late Holocene 
(a)

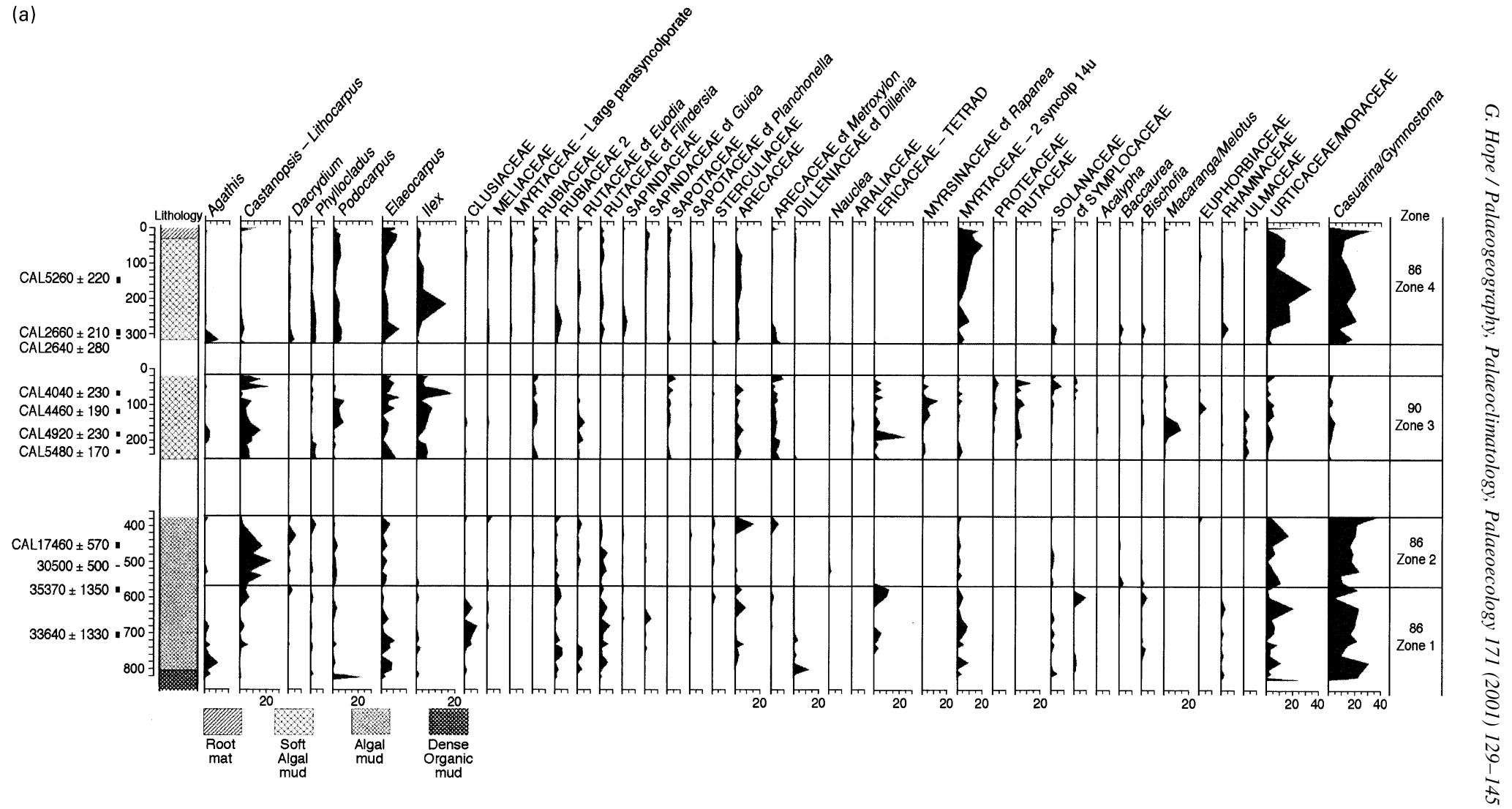

Fig. 4a. Pollen diagram from Wanda site, $445 \mathrm{~m}$. The 1986 core is split into an upper section (Zone 4) and Pleistocene zones (1 and 2). The 1990 core is interpolated as Zone 3. A dryland pollen sum of all trees and shrubs was used for primary forest and secondary taxa while a total pollen and spore count was used for other elements. Charcoal is given as mm per $\mathrm{ml}$ of sediment. The dendrogram was prepared from a classification of pollen percentages of major identified dryland plants. 


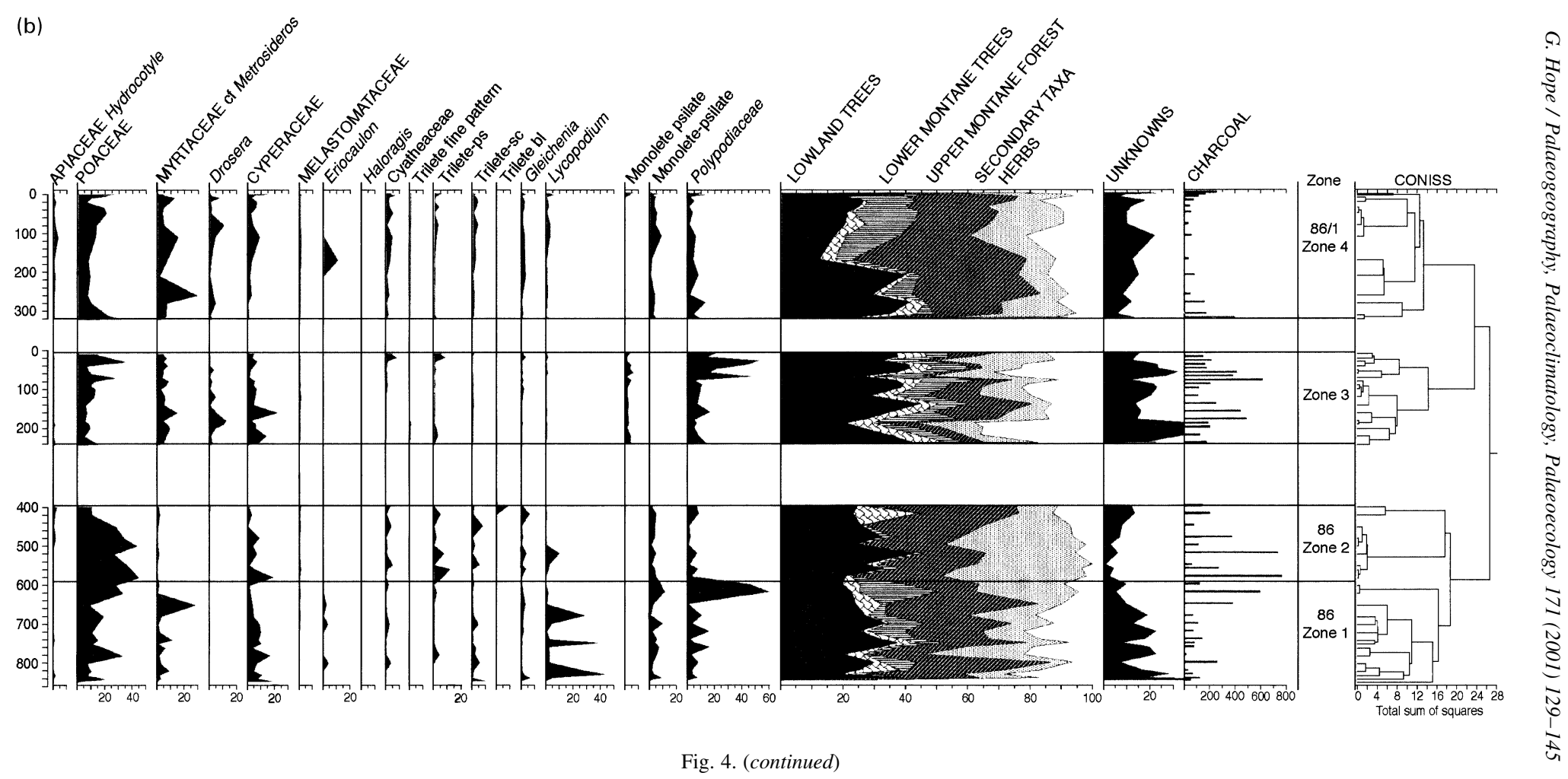


section of SKW86 from 0 to $360 \mathrm{~cm}$ lies above the SKW90 core which is interpolated as a distinct section covering the 3500-6000 year interval. The third section is the Pleistocene lower part of the SKW86 core from 390 to $846 \mathrm{~cm}$. A stratigraphically constrained classification (a TILIA routine) is shown which utilises only the elements in the dryland pollen sum which exceeded $2 \%$ in at least one level. The highest split in the dendrogram separates spectra in the last 6000 years from all previous spectra. The Pleistocene part of SKW86 is divided at a slightly lower level into two groups with three transitional clusters, and the diagram is divided into two Pleistocene and two Holocene zones.

Carbonised particles were counted using the point counting method of Clark (1982) and are presented as an area measure $\left(\mathrm{mm}^{2}\right.$ of charcoal per $\mathrm{ml}$ of sediment). Due to the loss of some original data some levels in the basal part of the core have been omitted, so histograms show all available levels. Charcoal is present in all levels examined, so gaps indicate missing data, not the absence of charcoal.

\subsection{Dryland pollen zonation}

The Pleistocene section (Zones 1 and 2) has no dominant pollen types but has a good representation of montane trees at different levels. The lowest two samples (which are poor in pollen), include a peak in the Podocarpus and Urticaceae-Moraceae pollen percentages with low percentages of Gymnostoma and Castanopsis. This may represent a separate zone derived from the basal compressed peats. Immediately above $840 \mathrm{~cm}$, percentages of Agathis, Gymnostoma, Elaeocarpus and Dilleniaceae type pollen rise and Ilex and Arecaceae are represented. The diversity of the source forest, indicated by Rutaceae, Clusiaceae (probably Calophyllum) and Ericaceae pollen, develops through the period of Zone 1 as Agathis percentages decline in importance. Zone 1 is separated from Zone 2 by a transition marked by short term declines in the representation of CastanopsisLithocarpus and Poaceae, and peaks in cf. Symplocus, Polypodiaceae and other monolete ferns.

Zone 2 is distinguished from Zone 1 by the highest percentages of Castanopsis-Lithocarpus, GymnostomaCasuarina and Poaceae pollen and possible tree fern spores in the diagram. Dacrydium type, Phyllocladus,
Podocarpus and Sterculiaceae have consistent levels. The pollen percentages of several mixed forest taxa decline or are lost, including Clusiaceae, Agathis, Euphorbiaceae, Ilex, Myrtaceae, Rhamnaceae and Ulmaceae. Metrosideros (Myrtaceae) pollen type, which may have either a swamp shrub or a forest tree sources, also declines to very low levels. Although clustered with the main Zone 2 spectra, the upper samples at 400 and $420 \mathrm{~cm}$ are distinct, with low percentages of Castanopsis-Lithocarpus and Poaceae pollen but very high Gymnostoma-Casuarina percentages.

Zone 3 is the SKW90 section, covering about 2000 years from the mid-Holocene. Mixed forest taxa are well represented with a great deal of variability. Taxa with marked better representation than in the Pleistocene zones are Elaeocarpus, Ilex, Rubiaceae, Sapotaceae, Arecaceae 2 (cf. Metroxylon) Ericaceae (or possibly Gardenia) Rapanea, Euphorbiaceae, Proteaceae (probably Macadamia hildebrandii) and Rutaceae. Castanopsis-Lithocarpus pollen has moderate levels with some variation. Poaceae is generally low, with isolated peaks. Fern spores are generally low except for marked peaks in Polypodiaceae in the upper part of the zone.

As discussed earlier, Zone 4 is potentially contaminated by older pollen. However the spectra show major distinctions from the other zones with the exception of the basal two spectra at 360 and $380 \mathrm{~cm}$ which closely match the top spectra of Zone 3 . These suggest a possible overlap with the top of SKW 90 in having a peak in Poaceae pollen, and matching percentages of Urticaceae-Moraceae, Arecaceae (Metroxylon type), Ericaceae-Gardenia and Metrosideros. However differences include high levels of Gymnostoma-Casuarina pollen, low Ilex and Castanopsis-Lithocarpus percentages, and the absence of Proteaceae, Rutaceae and Macarangal Mallotus.

There is no strong evidence for a high proportion of reworked Pleistocene pollen in Zone 4. The strongest match is the unmistakeable pollen of GymnostomaCasuarina, which is a major element in the Pleistocene and Zone 4 but almost absent from Zone 3. Pollen of Dacrydium, Maesa, Flindersia type, Sapindaceae, Nauclea and Baccaurea appear only in the Pleistocene zones and Zone 4, but none are very marked. Zone 4 is distinguished by much lower percentages of Castanopsis-Lithocarpus than in the 
other two zones while Myrtaceae, Urticaceae-Moraceae and Quintinia are much better represented than the other zones. Ilex has significant percentages in the upper half of the zone, in contrast to the Pleistocene zones. Zone 4 can, therefore, be regarded as reflecting late Holocene conditions and the final transition to the present day. The upper $15 \mathrm{~cm}$ has increases in the percentages of Poaceae, Arecaceae, CastanopsisLithocarpus and Urticaceae-Moraceae, and a decline in Gymnostoma-Casuarina pollen.

\subsection{Wetland pollen}

The pollen of swamp taxa, including Metrosideros, are not included in the calculations which establish the zonation because of the potential for overrepresentation and because percentage changes could be a reflection of aquatic and riparian vegetation responses to minor water level fluctuations. However changes to the frequencies of swamp taxa are remarkably consistent with the zone boundaries suggested by major dryland taxa. Cyperaceae pollen dominate the aquatic spectra in all zones, but fluctuate markedly, at times approaching zero. Meterosideros seems to have always been present and may have grown as a swamp tree, although its pollen is notably reduced in Zone 2. It has never formed a continuous swamp shrubland however, as its pollen reaches a maximum in Zone 4 when it has scattered cover in the swamp. This rise of Metrosideros percentages and the appearance of Drosera/Nepenthes and Eriocaulon only in the late Holocene, may indicate that the modern shallow water regime is developed in the last 5000 years.

Poaceae pollen may represent aquatic or riparian grasses in the past but grasses are absent from these niches in the modern depressions, due to very low fertility. Their pollen dominates Zone 2 and also has marked peaks in Zones 3 and 4. As nutrient demanding elements, an increase in riparian grasses suggests drying of the swamp and possible erosion from mature soils in the catchment. However the nutritional status of the lake cannot have changed much, or other aquatic elements such as Cyperaceae would have reacted in parallel. Thus it is probable that grass pollen is derived from terrestrial sources, and the peaks represent openings in the forest around the swamp.

\section{Vegetation history}

\subsection{Vegetation reconstruction}

High levels of tree pollen show that Wanda site has been surrounded by mixed closed forest throughout its history with openings at times for secondary species such as Macaranga-Melotus or Urticaceae/Moraceae and grassland. Although occurring in closed forest, Gymnostoma/Casuarina may be a regional pollen element as the modern source of its pollen today comes from steep disturbed slopes in the Larona valley, where it colonises landslips. Gymnostoma sumatrana is a stilt-rooted freshwater mangrove that lives in swamps in ultramafic terrains but this species has no local representation today, so the pollen type at Wanda is assumed to be terrestrial. The relative importance of montane forest elements in the past, compared to the present day, may reflect the presence of higher altitude forests at lower altitudes through the late Pleistocene. The base of the section below $830 \mathrm{~cm}$ is similar to the late Holocene in reflecting diverse communities and hence may reflect a similar environment. The undated Zone 1 may include levels of marine isotope Stage 3 age, or even conceivably last Interglacial (isotope Stage 5). The conifer Agathis seems to have been an important element in the oldest forests, reflecting stability and long periods for development.

Forest diversity seems to become reduced through the period leading up to ca. 30,000 yr B.P. The abundance of Castanopsis-Lithocarpus from around 30$15,000 \mathrm{yr}$ B.P. may indicate that greater dominance of Fagaceae occurred in the forest near the site, with a similar make up to that of higher altitude forest found above $850 \mathrm{~m}$ today. At the same time high levels of Poaceae are possibly an indication of some extralocal grasslands that occupied gaps in a more open forest. Alternatively, high levels of grass and sedge but low Metrosideros may indicate alternating dry conditions and deep flooding at the core site. The increase in charcoal during this time is then consistent with onsite fires in more extensive stands of burnable riparian or swamp taxa on the swamp floor.

The diversity of the forest in the Holocene record from 5500 to present suggests a closed canopy montane forest of similar form to the modern forest. There are rapid changes in species dominance possibly 
reflecting continuing disturbance and possibly rapid generational turnover in the Holocene (cf. Walker and Chen 1987). Transitional vegetation, with frequent open areas, may be indicated by high Casuarinal Gymnostoma and Poaceae levels, as occurs at the top of Zone 3.

\subsection{Climatic implications}

The possible local dominance of Castanopsis around the site ca. 35-17,000 yr B.P. indicates temperatures or cloudiness similar to the conditions above $800 \mathrm{~m}$. This could be interpreted as being due to a temperature lowering of at least $2.5^{\circ} \mathrm{C}$, assuming a moist lapse rate of $5.6^{\circ} \mathrm{C}$ per $\mathrm{km}$ altitude. If the suggested spread of terrestrial grasslands, fluctuating swamp conditions and the occurrence of frequent fires is accepted this may reflect open vegetation caused by lower precipitation or more seasonal climates than present. However, it is not possible to directly calibrate the Wanda site pollen data to modern samples to arrive at a palaeotemperature or effective moisture record. While an altitudinal sequence of pollen spectra could be collected, insufficient information is available to describe the growth climates at the different altitudes. The forests are spatially very variable, adding to the problem of obtaining characteristic spectra. Daily cloud lie varies dramatically over very short distances, and may have a major influence, compared to theoretical changes in lapse rate and total precipitation.

The lowest zone and Zones 3 and 4 are similar in reflecting diverse communities and conditions were presumably at least as warm and moist as present. Agathis forms extensive communities, in Halmahera and central Sulawesi at similar altitudes but on better soils than around Wanda Swamp, but the differences in climate are unknown.

\subsection{Human influences}

There is little that can be directly ascribed to human influence at the site. Carbonised plant debris and hence fire is present throughout the history of the site, reaching highest concentrations in the late Pleistocene, but with a second notable peak in the Zone 3 core. The top $10 \mathrm{~cm}$ shows a consistent increase in fine charcoal, presumably representing the recent historic period. Openings in the forest may be indicated by fluctuations in herb percentages. However, with the exception of GymnostomaCasuarina, the pollen of secondary tree taxa never reach high levels. Natural and human-lit fires are very uncommon in primary forest today so that the charcoal record may indicate substantially different conditions in the past, or long-term human disturbance on the swamp margin. The development of fish ponds appears to be a recent phenomenon, as there is little sign of former disturbance. The unexplained hiatus in the stratigraphy of SKW86 suggests the formation of an apparent hollow in the central zone of the swamp before 2500 years ago. Conceivably this may have had a direct or indirect human cause, particularly since the re-growth taxon Macaranga/Melotus is prominent just before this time.

The role of people in causing change over a very long period is equivocal here. While people may have visited the area and contributed to the fire regime their role has been minor over a very long period. Human occupation in Sulawesi has not been demonstrated beyond about 20,000 years (Bellwood 1997) although it may be of very great antiquity given the presence of Homo erectus since the middle Pleistocene on Java and Nusa Tenggara (Morwood et al., 1997). Given the lack of soil fertility it is not surprising that no extensive post-agricultural clearance has been found. Older sediments will need to be collected to establish if the fire regime can be ascribed to hunter-gatherer presence in the area.

\section{Regional comparisons}

While not at high resolution, the Wanda site record is a useful addition to long tropical records, as it represents an old terrestrial record from a geomorphologically stable site in the equatorial low altitude zone. The main comparative records are marine sequences from Halmahera and the Banda Sea (Barmawijaja et al., 1993; Van der Kaars, 1991, 1997; Van der Kaars et al., 2001) and a terrestrial record from Lake Tondano in northern Sulawesi (Dam et al., 2001). A published record from Danau Tempe, in South Sulawesi (Gremmen, 1992) records a Holocene estuarine sequence. The marine records show a palynological signal that generally matches the foraminiferal oxygen isotope signal so that it is clear that the 
regional vegetation is responding to global climate change. Van der Kaars distinguishes a lower montane forest dominated by Castanopsis-Lithocarpus in all the marine cores, with increasing signals from other montane forest elements such as Nothofagus brassospora and Phyllocladus in cores near New Guinea. He contrasts this group with lowland spectra dominated by fern spores and diverse groups including palms. From most cores Castanopsis-Lithocarpus shows a pronounced increase from late in isotope Stage 3 until the end of Stage 2, around 14,000 years B.P., coinciding with increased Poaceae percentages. No marked increase occurs during Stage 4 but the lowest levels of Castanopsis-Lithocarpus are found in the longer sections during the last and present interglacial times. Marine sediments reflect inputs of fluvial and airborne pollen from a very wide region so it is interesting that the regional marine sequence seems to be mirrored in the terrestrial records from Wanda. The 40,000 year core from Lake Tondano records higher Lithocarpus percentages in the earlier part of the diagram, falling abruptly before 13,000 years ago. Zone 2 at Wanda is in general agreement with these Stage $3 / 2$ records and this supports the general chronology inferred for the site.

The regional results also strengthen the case for supposing that the thermal environment was significantly altered at the LGM. Barmawidjaja et al. (1993) inferred from oxygen isotopes that very little change in sea surface temperature had occurred north of Halmahera despite the evidence for a significant expansion in lower montane forest. Thunell et al. (1994) extended this conclusion to the western Pacific Warm Pool generally. They suggested that increased lapse rates must have occurred to explain montane and alpine expansion. However this explanation is difficult to reconcile with the general maintenance of forest cover and the $6-8^{\circ} \mathrm{C}$ temperature decline implied by a snowline at $3450 \mathrm{~m}$ in Irian Jaya (Hope, 1996).

Lake Tondano was analysed for diatoms and a relative water level inferred (Dam et al., 2001). The lake was low prior to 33,000 year B.P. but expanded to larger than present until around 30,000 years ago when it may have become so dry that no sedimentation occurred until 13,000 years ago. This may also have been the pattern at Wanda Site, since only $50 \mathrm{~cm}$ of sediment built up between 35,000 and 17,000 years ago, and the early Holocene is missing. The swamp is a groundwater window that would be extremely sensitive to a shift in the water balance. The possible open conditions at Wanda (Zone 2) may parallel the dryer phase inferred from low lake levels at the same time at Lake Tondano. However there is no evidence, such as a layer of inorganic material or a horizon of logs, to indicate that the swamp was dry for an extended period.

In Sumatra, Newsome and Flenley (1988) record relatively modest changes in the level of montane forest at Danau Di Atas $\left(1^{\circ} \mathrm{S}, 1535 \mathrm{~m}\right.$ asl) and infer that the gymnosperm rich forests which occur above $1800 \mathrm{~m}$ surrounded the site at 22,000 cal yr B.P. From 35,000 until ca. $14,000 \mathrm{yr}$ B.P. the forests do not show great variation and there are only minor appearances of taxa currently occurring above $2500 \mathrm{~m}$. Possibly Danau Di Atas is situated within a broad band of Pleistocene montane forest that did not reach its altitudinal limits and hence the record appears conservative. The slightly lower Javan site at Situ Bayongbong $\left(6^{\circ} \mathrm{S}, 1250 \mathrm{~m}\right.$ asl, Stuijts 1993), records an incursion of lower montane forest from before 20,000 until 12,000 yr B.P., in closer agreement with the Sulawesi records.

Wanda lies between two long records in Irian Jaya and Java which display contrasting features due to their climatic settings. The 60,000 year record from Lake Hordorli at $780 \mathrm{~m}$ provides a clear indication for a former depression of lower montane forest next to the equatorial Pacific, confirming that Pleistocene climates were sufficiently cool and cloudy to cause significant and long lasting changes to the forest composition. There is no suggestion of drier conditions, and fire was absent until presumed anthropogenic burning commenced about 11,000 years ago. By contrast, the long record from $660 \mathrm{~m}$ altitude near Bandung (Van der Kaars and Dam, 1995, 1997) has relatively minor evidence for cooling but has phases indicating dryer conditions, including carbonate precipitation in the lake. Wanda appears to have a record with features of both sites. The area remains under forest and there is evidence for cooling but it also records frequent fires and some indications of drying.

These results suggest greater seasonality or interannual variability in the late Pleistocene as well as a reduction in overall precipitation. At present areas on 
the extreme south western arm, and in the lee of the highest mountains at Palu, have semi-arid climates. Wanda is on the lee side of mountains to the southeast which could have acted as a barrier to the southeast Trade winds during lower sea levels. This effect might have been enhanced if the height of the top of the Trade Wind system had also been lowered in the past as a result of lower sea surface temperatures. In addition the northern end of the Gulf of Bone, to the southwest of the site, would have been exposed in the Pleistocene. Although the coastline would have only been about $15 \mathrm{~km}$ further away than present this may have slightly reduced the daily thunderstorms which bring moisture inland.

Hence this near-equatorial site demonstrates considerable change for which a likely cause is lowered sea temperatures. The possible cause of lower sea surface temperatures would be increased upwelling or drift from the south and weakened throughflow from the Western Pacific Warm Pool to the Indian Ocean. There is a good prospect that the record at Wanda or other ultramafic basins in the Soroako area can be extended by using more robust coring equipment. Dating of the older phases remains a problem in these silica-free environments. The very deep Lake Matano should also contain a long term record of environmental change.

\section{Acknowledgements}

I am grateful to Mike Nichols (PT INCO) for showing me the karst basins in the Soroako area and to Arianto M., Djahadin Patadari, Iqbal Wahi, Bren Weatherstone and Alex Tandi for help with coring and vegetation survey. Permission to work in the lease of PT INCO was kindly obtained for me by Drs Benny Wahju. PT INCO provided much assistance and I am particularly thankful to Oking Gandamarja of Public Relations, Mine Manager Mr John Gill, Mr O. Samosir and Mr D. Waraspati of Mine Geology and Dr M. Jufri of Environmental Control for access to company reports and other information. Max van Balgooy released unpublished botanical data. In Canberra I am indebted to Dominique O'Dea, Ardrya Kovarch, and Wendy Southern for work on pollen and the plant collection and to Mr Lyn Craven for plant identifications. David Bulbeck provided unpublished data on prehistoric useage of the Matano area. The project was authorised by LIPI (SIP 10338 Sk. DIA B 5/1985) on the recommendation of my sponsor, the National Biological Institute, Bogor. The work was funded by Australian Research Grants E8215880 and A38615857 to G. Hope, and AINSIE grants for AMS determinations. Access to comparative site data was kindly provided by Sander van der Kaars, Monash University. I thank him, Rien Dam, Lydia Dupont, Peter Kershaw and Bob Morley for helpful advice.

\section{References}

Ahmad, W., 1977. Geology along the Matano Fault Zone, East Sulawesi, Indonesia. PT INCO, Indonesia.

Barmawijaja, B.M., Rohling, E.J., Van der Kaars, W.A., Vergnaud Grazzini, C., Zachariasse, W.J., 1993. Glacial conditions in the northern Molluca Sea region (Indonesia). Palaeogeography, Palaeoclimatology and Palaeoecology 101, 147-167.

Bellwood, P., 1997. Prehistory of the Indo-Malaysian Archipelago. University of Hawai'i Press, Honolulu.

Bellwood, P., 1998. The archaeology of Papuan and Austronesian prehistory in the Northern Mollucas, Eastern Indonesia. In: Blench, R., Spriggs, M. (Eds.), Archaeology and Language II: Correlating Archaeological and Linguistic Hypotheses. Routledge, London, pp. 128-139.

Bulbeck, F.D., Prasetyo, B., 1999. The origins of complex society in South Sulawesi. Unpublished report to Lembaga Ilmu Pengetahuan Indonesia, Jakarta.

Clark, R.L., 1982. Point count estimation of charcoal in pollen preparations and thin sections of sediments. Pollen et Spores 24, 523-535.

Cox, R., Collins, N.M., 1991. Indonesia. In: Collins, N.M., Sayer, J.A., Whitmore, T.C. (Eds.), The Conservation Atlas of Tropical Forests Asia and the Pacific. Macmillan, London, pp. 141-165.

Dam, R.A.C., Fluin, J., Suparan, P., Van der Kaars, W.A., 2001. Palaeoenvironmental developments in the Lake Tondano area (North Sulawesi, Indonesia) since 33,000 B.P. Palaeogeography, Palaeoclimatology, Palaeoecology 171, 147-183.

Gremmen, W.H.E., 1992. Palynological investigations in the Danau Tempe depression, southwest Sulawesi (Celebes), Indonesia, 11.

Grimm, E., 1988. Data analysis and display. In: Huntley, B., Webb, T. III (Eds.), Vegetation History. Kluwer, Dordrecht, pp. 43-76.

Haberle, S., 1994. Anthropogenic indicators in pollen diagrams: problems and prospects for late Quaternary palynology in New Guinea. In: Hather, J. (Ed.), Tropical Archaeobotany: Applications and New Developments. Routledge, London, pp. 172-201.

Hope, G.S., 1996. Quaternary change and historical biogeography of Pacific Islands. In: Keast, A., Miller, S.E. (Eds.), The Origin and Evolution of Pacific Island Biotas, New Guinea to Eastern Polynesia: Patterns and Process. SPB Publishing, Amsterdam, pp. 165-190. 
Hope, G.S., Pask, J., 1998. Tropical vegetational change in the late Pleistocene of New Caledonia. Palaeogeography, Palaeoclimatology, Palaeoecology 142, 1-21.

Hope, G.S., Tulip, J., 1994. A long vegetation history from lowland Irian Jaya. Indonesia. Palaeogeography, Palaeoclimatology, Palaeoecology 109, 385-398.

Hope, G.S., Gillieson, D., Head, J., 1988. A comparison of sedimentation and environmental change in New Guinea shallow lakes. Journal of Biogeography 15, 603-618.

Metcalfe, I., 1990. Allochthonous terrane processes in Southeast Asia. Phil. Trans. Roy. Soc. Lond. A 331, 625-640.

Morley, R.J., 1981. Development and vegetational dynamics of a lowland ambrogenous peat swamp in Kalimantan Tengah, Indonesia. J. Biogeography 8, 383-404.

Morwood, M.J., Aziz, F., Van den Bergh, G.D., Sondaar, P.Y., De Vos, J., 1997. Stone artefacts from the 1994 excavation at Mata Menge, West Central Flores, Indonesia. Australian Archaeology 44, 26-34.

Newsome, J., Flenley, J.R., 1988. Late Quaternary vegetational history of the central highlands of Sumatra-II. Palaeopalynology and vegetational history. J. Biogeography 15, 555-578.

Pigram, C.J., Davies, H.L., 1987. Terranes and the accretion history of the New Guinea orogen. Bureau of Mineral Resources Journal of Australian Geology and Geophysics 10, 193-211.

Soeria Atmadja, R.S., Golightly, J.P., Wahju, B.N., 1974. Mafic and ultramafic rock associations in the east arc of Sulawesi. Proc ITB 8 (2), 1-19.

Stuijts, I., 1993. Late Pleistocene and Holocene vegetation of West Java, Indonesia. Modern Quaternary Research in S.E. Asia, 12.

Stuiver, M., Braziunas, T.F., 1993. Dataset for radiocarbon calibration. The Holocene 3, 289-305.
Thunell, R., Anderson, D., Gellar, D., Miao, Q., 1994. Sea surface temperature estimates for the tropical west Pacific during the last glaciation, and their implications for the West Pacific warm Pool. Quaternary Research 41, 255-261.

Van Balgooy, M.M.J., Tantra, I.G.M. 1986. The vegetation in two areas in Sulawesi, Indonesia. Bulletin Penelitian Hutan, Special Edition, pp. 1-61.

Van der Kaars, W., 1991. Palynology of eastern Indonesian marine piston-cores: a Late Quaternary vegetational and climatic record for Australasia. Palaeogeography, Palaeoclimatology and Palaeoecology 85, 239-302.

Van der Kaars, W.A., 1997. Marine and terrestrial pollen records of the last glacial cycle from the Indonesian region: Bandung basin and Banda Sea. Palaeoclimates, Data and Modelling 4, 1-11.

Van der Kaars, W.A., Dam, M.A.C., 1995. A 135,000-year record of vegetational and climatic change from the Bandung area, West-Java, Indonesia. Palaeogeography, Palaeoclimatology Palaeoecology 117, 55-72.

Van der Kaars, W.A., Dam, M.A.C., 1997. Vegetation and climate change in West Java, Indonesia during the last 135,000 years. Quaternary International 37, 67-71.

Van der Kaars, W.A., Wang, X., Kershaw, A.P., Guichard, F., Setiabudi, D.A., 2001. A late Quaternary palaeoecological record from the Banda Sea, Indonesia: patterns of vegetation, climate and biomass burning in Indonesia and northern Australia. Palaeogeography, Palaeoclimatology, Palaeoecology 171, 185-213.

Walker, D., Chen, Y., 1987. Palynological light on tropical rainforest dynamics. Quaternary Science Reviews 6, 77-92.

Whitten, A.J., Musliman, M., Henderson, G.S., 1987. The Ecology of Sulawesi. Gadjah Mada University Press, Yogyakarta. 